\title{
School librarian, a successful job!
}

\author{
Janneke H. Krommendijk-Eshuis \\ C.s.g. Reggesteyn \\ P.O. Box 120, \\ NL 7440 AC Nijverdal \\ The Netherlands \\ j.krommendijk@reggesteyn.nl
}

Keywords: Reggesteyn, Reading project, Informational Literacy skills, Commitment, Library school committee, Netherlands

\section{The school library}

The school library situated on the Noetselerbergweg, Nijverdal is open from 08.00 in the morning until 4.30 in the afternoon, and is fully integrated into school life. Students know where to find the school library, even when the school day is at an end, whether it's to work on a project, find a particular book, do necessary research or just to browse through the available magazines and newspapers. There is always something to do. It would appear to be quite normal, a school library buzzing with life, but a lot of hard work has gone into achieving this.

\section{Make sure everyone uses the school library!}

This objective, easier said than done. Everything starts at the counter at the library. That is the place to ask questions and get information. 'Do you know where I can find (a book about Nelson) Mandela?'. Or what about the young girl who was convinced that 'slufters' don't exist. She could not find anything, neither could her daddy and he used Google! There is nothing more satisfying than to find some information, on the internet or in the library! The library is well- known to the students, but how does the librarian reach the teachers? This is achieved by personal contact, either in the lunch area or while walking through the corridors. Department meetings were also attended in order to promote the possibilities of the school library.

\section{Embedded in the educational system}

At what point is the school library completely embedded within the educational system? The school library commission plays a prominent role. The task of this commission (members: two teachers, the librarian and a member of the management) is turning school policy into school library policy. For teachers it isn't always clear what contribution the school librarian can give within the teaching process, sometimes the librarian is seen as a 'busy body'. Her expertise however, proves her worth. The Librarian is an information specialist and by providing educational support and thinking through the didactics, he or she can become an equal associate.

The school librarian takes part in most assignments, provides extra information and orders the necessary material for projects. Students are also given guidance when gathering information for pieces of work, lessons are given in methods of research and all first year students are given introduction lessons showing them the wonders of the school library. The 
librarian works closely together with the Remedial Teaching team, especially when it concerns students with reading problems such as dyslexia. Teachers also work together with the school librarian in preparing certain lessons. This is time saving as information is collected for them! One of the most enjoyable tasks for the school librarian is organizing workshops for students, teachers and even parents during parents' evening, in which the modern school library is brought to life.

\section{A successful school library?}

Basic factors which contribute to the success are:

- Knowledge and commitment by the school management.

- A powerful school library commission

- The close co-operation with all public libraries in the immediate vicinity and the RBG (Library services for Overijssel). The school ID card for example, can be used at school and also for borrowing books in the local library.

- The connection with the local public libraries' network in the province of Overijssel.

With everything automated, does this mean that there is nothing more to do? Oh, no, there is always regular work next to participating in tasks and being innovative. What is required? Knowledge about new educational principles, in the school system, in given education and the expected examination subjects. Looking for innovation, renewal and development and of course not being blind to the weaknesses and threats that could possibly harm the school library. The school librarian is the person who has a vision and who shares that vision.

Two projects making me very happy: 'Vrij vrolijk lezen' (reading for joy) and 'de doorlopende leerlijn informatievaardigheden' ( the continuing learning curriculum in information literacy).

This reading project started (2010) as a pilot in two classes, then (and also now) it is not bound to a specific branch. During the lesson the teacher is reading just like the students. There is no time for checking homework or other little jobs. The attention is purely and solely addressed to reading. The thinking behind this: students work on their vocabulary with pleasure in reading, and more importantly focus their attention upon better results in future. It is so rewarding to do!

In 2015, reading has been embedded in the school program. Every student in the lower forms has a reading book in their school bag, for reading (one or more lessons a week), for use if the lesson doesn't fill a complete period, or during spare time after taking a test . Required for success: Support by management and teachers, extra money by way of collection for this specific new purpose. And the continued co-operation between Remedial teaching and the school librarian.

'Information literacy skills', was grounded by the school library commission. More than anything else was the behavior of our students seen in the library. They are not good at finding, retrieving or analyzing information or verifying sources. And committing plagiarism? Not a good idea! Teachers and parents often assume that students know how to find the correct information, but they rarely check this actually happens. How does one bring about change? And when there is change, how to ensure it is directly allied to all the departments in school. This will be my crusade. How and where did I start? 
By reading professional literature and the master class given by Mr. Albert Boekhorst (University of Amsterdam) both of which were very important to me. I reported what I had learned, about principles of Marzano and new education of the 'big 6' to the library school commission. And then it started, in 2005. Questions were asked to the management about the responsibility at our school for information literacy skills and was there any development? Only a vague response was given. We, Mrs. Duenk,( History teacher and member of the school library commission) and I started what was later called 'Commission information literacy'.

This commission started by looking for support. This was done by continuing to stay in contact with teachers, promoting our ideas about the big 6 and the importance of those skills in schoolwork. We were able to start with reviewing and renewing the workbook for the' profile project' (an extensive essay which is part of the final diploma mark) to be used in the last school year. The new workbook is grounded on the principles of Marzano and parts of 'the big 6'.

The most important step is taken by our students before starting their assignment. They activate their knowledge, then make one or two mind maps. Then it is time to determine what information is needed. Verify the information found and the sources. Start searching again, if necessary, then the writing can start. Finally, it is time for the presentation and evaluation. There are new assessment sheets, built up for the Alpha as well as the Beta department, with the focus on the process and less on the result.

What did I do? Talking, talking about the target and possibilities at our school. Saying "it is nothing new, only more structured in simple small things, providing better results for our students". Writing in the 'weekly staff letter' about recognizable situations in the school library. Writing about 'slufters not existing' for example! Slowly the interest for information literacy skills came from the lower forms. Mrs. Duenk and I translated our work for use in the lower forms. Information literacy skills can be found on the electronic learning environment (elo).

There has been a success rate of $70 \%$ (even more) for information literacy skills in the two sixth form classes of our school. Some progress has been made in the lower forms, but has not transferred completely to all the departments. It is hard to imagine that a student does not use knowledge learned from one teacher automatically with other teacher. It is clear, information literacy skills should be used by all teachers in the same way. As a pilot, children of the primary school in Nijverdal used our more simplified skills. And it worked! I think we can conclude that working with fixed patterns will give students support in completing their assignments. And the quality of the work is better!

\section{Problems...pitfalls..... and?}

One step forward, two backwards, this is how it feels for me. Being supported by the management is important to motivate teachers and to bring them onto the same page. And many changes in the management proved to be sometimes very disappointing for our project. New problems start when the project is ongoing. Not using the workbook, laborious co-operation, not enough attention paid to plagiarism. Or simply: lack of funding: ' please ask again next year!' And headaches about hardware and software not working. Needed: staying attentive and take action when it is needed to keep the project ongoing! 
Very important is the co-operation between Mrs. Duenk (teacher+ member of the library school commission) and myself. With input from the education practice and the school library, we share our experiences and think about solutions. Now with information literacy skills in the school program, our idea has been brought to life. And the project goes on, even when we are both less involved.

The school library and future plans:

- Staying involved with information literacy skills

- Being involved with additions or changes to the Dutch/ French, English and German literature lists. One idea is to choose books which give the students information on other subjects in the curriculum. Compulsory reading for Dutch literature while at the same time learning for History, Geography or Social studies. This will help them broaden their knowledge regarding other subjects.

- Encouraging work on projects together with the public library, the RBG, and other local cultural partners.

\section{Personal note}

There are some factors which give me cause for concern. One is the need for information literacy skills ,for example. It is of paramount importance to convince students of the necessity to verify all the information they find. Further serious thoughts about the profession of school librarian: Is the librarian part of the teaching staff or the administrative section? As a school librarian you cannot fix it by yourself. In the school library at the Noetselerbergweg we work as a team. The librarian, the librarian assistant and some volunteers. For me it is a chance to do my work in the school! Despite any misgivings I must say that I enjoy my work as school librarian immensely. We (the library) are here to help! And we do it gladly and with vision!

\section{References}

Krommendijk- Eshuis, J.H. (2009). De kansen voor het onderwijs liggen in het uitdagen van leerlingen: leren en lezen leuk maken. In: Mediacoach. Jrg. 2, nr. 4, pag. 10-11.

Van Lesuur naar leesuur: CSG Reggesteyn wakkert de leeshonger aan. In: VO magazine. 2013. Jrg. 7, no. 3, pag 24-27

Vrij Lezen. Amersfoort: CPS. www.youtube.com/watch?v=ICzh1Yg9AS4

Fiori, Lucia. (2014). Vrij lezen als motor voor betere prestaties, motivatie en relatie (blog). http://www.cps.nl/blog/2014/05/16/Vrii-lezen-als-motor-voor-betere-prestaties$\underline{\text { motivatie-en-relatie }}$

Besselink, P. en M. van den Berg. (2010) Informatievaardigheden op school: Een pleidooi voor een serieuze aanpak. In: Media Coach, jrg. 3 no. 1 page 27-31.

Boekhorst, A. (2004) Informatievaardigheden.

Marzano, R. (1992). A different kind of classroom: teaching with dimensions of learning

Van Veen, M.J.P. Informatievaardigheden voor docenten. Heerlen: Open Universiteit. 
http://www.ou.nl/Docs/Expertise/RdMC/Folder informatievaardigheden.pdf

Van Veen, M.J.P. (red.) (2005). Door de bomen het bos. Heerlen: Open Universiteit. http://www.ou.nl/Docs/Expertise/RdMC/RDMC door de bomen.pdf

Note: C.S.G. Reggesteyn on the Noetselerbergweg in Nijverdal provides educational facilities for (approximately 1200) students wishing to gain the necessary certificates needed for admittance to either college or university. See: www.reggesteyn.nl 